\title{
Engaging Undergraduates in Science Research: Not Just About Faculty Willingness
}

\author{
M. Kevin Eagan Jr. • Jessica Sharkness • Sylvia Hurtado • \\ Cynthia M. Mosqueda $\cdot$ Mitchell J. Chang
}

Received: 23 August 2010/Published online: 29 October 2010

(C) The Author(s) 2010. This article is published with open access at Springerlink.com

\begin{abstract}
Despite the many benefits of involving undergraduates in research and the growing number of undergraduate research programs, few scholars have investigated the factors that affect faculty members' decisions to involve undergraduates in their research projects. We investigated the individual factors and institutional contexts that predict faculty members' likelihood of engaging undergraduates in their research project(s). Using data from the Higher Education Research Institute's 2007-2008 Faculty Survey, we employ hierarchical generalized linear modeling to analyze data from 4,832 science, technology, engineering, and mathematics (STEM) faculty across 194 institutions to examine how organizational citizenship behavior theory and social exchange theory relate to mentoring students in research. Key findings show that faculty who work in the life sciences and those who receive government funding for their research are more likely to involve undergraduates in their research project(s). In addition, faculty at liberal arts or historically Black colleges are significantly more likely to involve undergraduate students in research. Implications for advancing undergraduate research opportunities are discussed.
\end{abstract}

Keywords Undergraduate research experience - STEM faculty · Mentorship · Hierarchical generalized linear modeling · Organizational climate

\section{Introduction}

Students who initially enter college with the intention of majoring in science, technology, engineering, or mathematics (STEM) fields have substantially lower completion rates in these disciplines than do their peers who enter with aspirations for a non-STEM major (Huang et al. 2000). Compounding this problem, under-represented racial minority (URM) students in STEM have extremely low bachelor's degree completion rates, especially when compared with their White and Asian American counterparts. A Higher Education Research Institute (HERI) report indicated that just $24.5 \%$ of White students and $32.4 \%$ of

M. K. Eagan Jr. $(\bowtie)$ - J. Sharkness · S. Hurtado - C. M. Mosqueda · M. J. Chang University of California, 405 Hilgard Ave., 3005 Moore Hall, Los Angeles, CA 90095-1521, USA e-mail: mkeagan@gmail.com 
Asian American students who entered college with the intention of majoring in a STEM field completed a bachelor's degree in STEM within four years while $15.9 \%$ of Latino, $13.2 \%$ of Black, and $14.0 \%$ of Native American students did the same (HERI 2010).

Given the low retention and degree completion rates of students who initially choose to major in STEM, policymakers have called for STEM faculty to help retain students by engaging students in innovative strategies that aim to enhance scientific competencies both inside and outside of the classroom (Committee on Science, Engineering, and Public Policy 2007). To incentivize such innovation, federal agencies have provided funding to support the development and implementation of programs designed to improve completion rates in STEM and to encourage students to pursue doctorates in these fields. One type of program that falls under this umbrella is the undergraduate research experience, which provides students with hands-on training in which they apply classroom knowledge to realworld problems (Seymour et al. 2004). Researchers have documented many benefits of research participation for undergraduates, including improved ability to think and work like a scientist, clarification of career plans, improved preparedness or desire for graduate study, and higher STEM retention rates (Espinosa 2009; Hunter et al. 2006; Laursen et al. 2010; Seymour et al. 2004).

On campuses where structured research programs do not exist or where large proportions of students do not participate in such programs, faculty must themselves offer research training to students if they want students to have hands-on research experience. Working with a faculty member on a research project, whether within or outside of a formal research program, not only provides the hands-on training identified by Seymour et al. (2004) but also allows students to establish closer ties with faculty members. Previous research has shown that having meaningful interactions with faculty can increase STEM students' chances of persisting to degree completion in their chosen field (Cole and Espinoza 2008).

Unfortunately, few studies have explored the factors that influence faculty members' decisions to include undergraduates in their research. In one of the only studies examining predictors of engaging undergraduates in research, Einarson and Clarkberg (2004) found that, on one campus, teaching undergraduate courses, having outside funding, and being a junior faculty member positively predicted professors' inclusion of undergraduates in research. By contrast, faculty who primarily worked with graduate students or found it difficult to interact with undergraduates tended to be less likely to conduct research with undergraduates. Faculty also face institutional and departmental obstacles in involving undergraduate students in research, as promotion and tenure systems typically emphasize research productivity over engagement with and mentoring of undergraduate students (O'Meara and Braskamp 2005). No previous studies have undertaken a comprehensive multi-campus analysis of faculty data to predict faculty members' decisions to involve undergraduates in their research. This study utilizes data from a national survey of faculty to understand the individual and institutional predictors of professors' likelihood of engaging undergraduates in research.

Issues of Faculty Workload

Faculty face significant barriers to including undergraduate students in their research projects. These barriers include a heavy workload, a reward structure that does not incentivize mentoring students, limited funding, and the potentially daunting amount of time required to mentor and train undergraduate researchers. Scholars consistently have found that faculty time is notoriously scarce, as professors at all ranks regularly work over 
50 hours per week and tend to feel that core responsibilities like teaching and service make it difficult to focus on research (Jacobs and Winslow 2004; Link et al. 2008; Sharobeam and Howard 2002). Even with the difficulty in finding the time to devote to research, faculty continue to publish, as it is one of the activities most rewarded when promotion and tenure decisions are made. Although many colleges have tried to increase faculty engagement with students, they have not deemphasized the importance of research. Indeed, O'Meara and Braskamp (2005) found that, although chief academic officers had increased their expectations of faculty members' engagement with students between 1991 and 2001, these expectations had increased at a slower rate than did research productivity benchmarks.

Given that faculty time and workload eventually becomes a zero-sum game, where more time on teaching results in fewer hours being devoted to research and vice versa, an examination of the factors that predict faculty members' likelihood of engaging undergraduates in research needs to consider the ways in which faculty allocate their time. Faculty workload has risen across all institutions during the last 25 years (Milem et al. 2000; Schuster and Finkelstein 2006; Townsend and Rosser 2007), but the activities that faculty spend their time on continue to vary by institutional type. For example, Townsend and Rosser (2007) found that faculty members at research universities averaged the greatest number of hours engaged in research, published the most articles in refereed journals, and presented most frequently at conferences; however, these faculty also ranked lowest in classes taught and total credit hours in classes per week. The variation in faculty time allocation likely has a connection to the incentive structures in place at institutions, as colleges and universities tend to offer the greatest rewards to professors who spend the most time engaged in research and who are most productive in publishing (Aguirre 2000; Blackburn and Lawrence 1995; Rice 1986). Regardless of Carnegie classification, research-oriented faculty are typically paid more than their teaching-oriented colleagues (Bland et al. 2005; Fairweather 1993, 1997, 2005; Porter and Umbach 2001; Townsend and Rosser 2007). In addition to increased pay, research-oriented faculty members derive greater tangible and intangible rewards, such as tenure and status within their institution and discipline, from having a more productive research agenda (Park 1996; Schuster and Finkelstein 2006).

Not only does the way in which faculty allocate their time vary across institutions but it also differs by gender, race/ethnicity, rank, tenure status, discipline and marital status (Antonio 2002; Bellas and Toutkoushian 1999; Park 1996; Turner 2002). For example, Bellas and Toutkoushian (1999) found that, on average, male professors devoted more time to research than did their female counterparts. Furthermore, this time allocation also differed across academic rank, as female full professors spent the fewest hours per week teaching but the most amount of time in service roles. However, there has been some disagreement on the relationship of faculty demographics and time allocation. Some scholars have suggested that female faculty and faculty of color spend the most time on teaching or in service, but Olsen et al. (1995) did not find evidence to support this hypothesis. Other scholars have suggested that ethnic minority faculty place greater importance on research and spend more time conducting research each week compared to their White colleagues (Antonio 2002). Given this body of evidence, any study that examines issues of faculty workload and engagement with students needs to consider the demographic characteristics of faculty that are associated with workload patterns.

Less contested is the fact that the number of hours that faculty spend on various activities per week tends to change as faculty advance in academic rank (Bellas and Toutkoushian 1999). Non-tenured faculty typically spend the most time teaching each week, and full professors generally spend more time on research than do assistant 
professors. Further, research university faculty in engineering, health sciences, and the natural sciences tend to spend less of their time teaching and more in research than do their colleagues in humanities, fine arts, and social sciences (Fairweather and Beach 2002).

Because of the many demands placed upon faculty, student-faculty collaboration may be challenging and not as beneficial for faculty as it is for undergraduate students (Harvey and Thompson 2009). Implementing and maintaining a research program with students is time-intensive and requires institutional support, faculty commitment, and support staff to ensure success (Davis et al. 2005). Even if faculty have a desire to work with undergraduate students on research projects, doing so can be very difficult if faculty lack appropriate support (Merkel 2001; Prince et al. 2007). Furthermore, not all faculty desire to spend their time with undergraduates in the lab; some faculty have cited concerns that integrating undergraduates on research projects may hinder their productivity, as they may end up spending more time training and orienting undergraduates to the lab or research project than they do actually conducting research (Prince et al. 2007). Harvey and Thompson (2009) underscore this point, as they note that "a significant barrier to research productivity at [predominantly undergraduate institutions] is availability of time; and faculty efficiency and time balancing therefore become a major consideration when engaging students in research" (p. 13).

\section{Faculty Mentorship}

Although it can be time-intensive on the part of faculty, the benefits of mentorship for students are well documented (Crisp and Cruz 2009; Jacobi 1991). Benefits also have been shown specifically for undergraduates involved in research programs (Ishiyama 2007; Kardash 2000; Laursen et al. 2010; Seymour et al. 2004) and for underrepresented minority students (Lee 1999; Santos and Reigadas 2002). Most of this literature demonstrates cognitive and affective gains for students, such as increased retention rates, higher grade point averages, and greater clarity of academic and career goals. However, although the mentoring literature has demonstrated that mentoring relationships have mutual benefits for both the mentor and the protégé (Newby and Heide 2008), evidence documenting faculty motivation to become mentors and the benefits of mentorship for faculty is lacking. The existing research is mainly anecdotal or is focused on single programs (Campbell and Campbell 1997; Kardash 2000).

Several studies have discussed disincentives that faculty face that influence their mentoring behavior (Johnson 2002; Merkel 2001; Prince et al. 2007). Obstacles can exist at multiple levels: institutional, departmental, and individual (Johnson 2002). At the institutional level, many colleges and universities implement "university accounting systems that reward faculty exclusively for funded research and publications, typically at the cost of teaching and mentoring" (Johnson 2002, p. 90). In other words, many institutions adopt policies that result in low likelihoods of faculty members being rewarded by the institution for their work with students. As a result, faculty may choose to focus their efforts in areas that offer demonstrated, tangible rewards. Likewise, on a departmental level, Johnson (2002) notes that little, if any, incentives exist for faculty to mentor students, as many departments or units within higher education institutions do not offer faculty financial compensation, reduced course loads, or accelerated opportunities to achieve tenure for being excellent mentors.

In addition to the institutional and departmental disincentives, faculty also may be discouraged from becoming mentors to undergraduates at the individual level if they have few opportunities to establish meaningful relationships with students. Johnson (2007) notes 
that large class sizes and high undergraduate student-faculty ratios make connecting with and mentoring individual students more challenging. Moreover, the undergraduate experience in certain disciplines is brief, as some students delay declaring a major for a year or more and therefore spend only 2-3 years fully engaged in a specific department. Finally, undergraduate students tend to rely on faculty to establish mentoring relationships, as many students lack the self-awareness or assertiveness to find a mentor on their own (Johnson 2007); faculty, on the other hand, may be waiting for students to approach them looking for opportunities.

\section{Organizational Citizenship and Social Exchange Theory}

Given that faculty workload demands and institutional disincentives may discourage faculty from including undergraduates on their research projects, we draw from a model of organizational citizenship behavior to understand why some faculty may choose to work with undergraduates on research despite these potential barriers. McManus and Russell (1997) define organizational citizenship as "exerting more effort on the job than is required or expected by formal role prescriptions" (p. 148). Such a framework is appropriate for studies of faculty members' propensity to work with students, as establishing a collaborative research relationship with undergraduate students represents an endeavor that exceeds most institutions' expectations of faculty. The link between a faculty member's decision to mentor a student and organizational citizenship behavior becomes even more apparent when considering that, in many cases, faculty acting as mentors provide "assistance to protégés without that behavior being mandated or compensated by the organization" (McManus and Russell 1997, p. 149).

Early research on organizational citizenship behavior identified five dimensions of the construct: altruism, conscientiousness, sportsmanship, courtesy, and civic virtue (Organ 1988). Altruism relates to individuals' desire to help others in face-to-face settings; examples include volunteering for additional duties or helping to orient others within the workplace. Conscientiousness corresponds to following the norms of the organization, and sportsmanship relates to whether individuals maintain a positive attitude and avoid complaining about trivial matters. Courtesy connects to the extent to which employees collaborate and consult with others before making a decision. Finally, the dimension of civic virtue corresponds to the frequency with which individuals remain updated on news affecting the organization.

Given the complexity of the five dimensions of organizational citizenship behaviors identified by early scholars, Organ and Ryan (1995) condensed these traits into two primary components: (1) actions and decisions targeted for certain individuals and (2) activities directed at an organization. Individuals may have a greater inclination to perform functions outside their prescribed responsibilities if they are satisfied with their job and have a strong commitment to their organization or institution (McManus and Russell 1997), which certainly seems to be true for faculty, as past studies have linked faculty members' job satisfaction and overall morale with their commitment to their work (Bland et al. 2005; Johnsrud and Rosser 2002; Mamiseishvili and Rosser 2010). Similarly, both organizational citizenship theory and past research suggest that if individuals believe that a role outside of their prescribed duties, such as mentoring, is actually an integral part of their work, they are more likely to voluntarily engage in the activity (Herzberg 1966; Judge et al. 2001; McManus and Russell 1997).

Although the organizational citizenship framework primarily has been used in the management and human resource literature to examine mentoring relationships in the 
corporate world, it can be extended to higher education. Faculty members who have a stronger commitment to their institution, whether because they believe their values are congruent with the institution or because they believe in the direction and overall mission of their college or university, may have an increased likelihood to go beyond their official job responsibilities by serving in a mentoring role to undergraduate students (Doherty 1988; Johnsrud and Rosser 2002). Likewise, faculty who have a more positive view of undergraduates at their institution and who spend more time with undergraduates may have an increased probability of wanting to work with undergraduates on faculty-directed research projects.

Faculty members' decisions to include undergraduates on research projects can also be understood through the lens of social exchange theory. Linked to the framework of organizational citizenship behavior, social exchange theory suggests that individuals choose to engage in relationships that they expect to offer beneficial personal outcomes (Emerson 1981; Lawler and Thye 1999). Social exchange theory postulates that when entering into relationships, individuals weigh the perceived costs and benefits of such a connection, as the parties involved exchange something of value (Emerson 1981). In the case of faculty including undergraduates on their research project, faculty offer undergraduate students time and knowledge while undergraduate research participants offer faculty labor, albeit in a limited form. Social exchange theory does not suggest that all relationships must offer an equal sense of reciprocity to both parties involved, but, if relationships are unbalanced, a power dynamic may result (Emerson 1981). Although generally applied to romantic relationships, social exchange theory has been utilized in studies on mentoring in general (Gibb 1999; Hegstad 1999) and in studies specifically focused on faculty's mentoring of students (Griffin 2008).

In the broader context of faculty members' responsibilities and obligations to the institution, social exchange theory suggests faculty may weigh the potentially high costs and limited benefits of involving themselves with undergraduate students on research projects before they embark on such an endeavor. Faculty members who perceive little reward for themselves, who have limited interest in mentoring, or who simply have limited time to invest in a mentoring relationship with an undergraduate student may be disinclined to include undergraduates on their research projects. Conversely, when faced with limited resources, when driven by a personal belief in undergraduate education, or when working in teaching institutions, faculty may feel that it is a fair "exchange" to teach undergraduates how to conduct research because it not only advances some of their own work but also advances personal goals of contributing to the development of young scholars who may be underrepresented in their field (Griffin 2008).

We draw from the frameworks of organizational citizenship behavior and social exchange theory as well as from the literature on faculty workload and mentoring in proposing the conceptual framework that guides this study. Given that faculty workload in areas of teaching and service correspond to the amount of time faculty can devote to research activities (Jacobs and Winslow 2004; Link et al. 2008; Sharobeam and Howard 2002), we suggest that measures of time that faculty devote to teaching and other scholarly activities directly affects their ability to include undergraduates on their research projects. Prior research also has documented variations in time allocation and mentorship tendencies based on demographic characteristics and professional characteristics (Antonio 2002; Bellas and Toutkoushian 1999; Van Dyne et al. 1994), so we also include these in our guiding framework. Further, given the significant variation in faculty members' connection to undergraduates and workload across institutional types (Townsend and Rosser 2007), we suggest that institutional contexts, including 
institutional type, control, and selectivity, significantly predicts whether faculty engage undergraduate students in their research.

Organizational citizenship theory suggests that members of organizations may display organizational citizenship behavior via actions that are beyond their prescribed duties and that directed towards individuals (Organ and Ryan 1995). In this study, we view faculty including undergraduates on their research project as a demonstration of organizational citizenship behavior. Research suggests that job satisfaction of organizational members and their perceptions of the organizational climate predict the extent to which individuals demonstrate organizational citizenship behavior (Johnson 2002; Merkel 2001; Prince et al. 2007). Therefore, we include in our guiding framework a series of measures about faculty perceptions of the climate at their institution as well as measures of whether faculty feel their values are congruent with the dominant institutional values. We also incorporate in our model measures of faculty's commitment to undergraduate education, as we view this as a potential catalyst for devoting additional time and resources to mentor undergraduates.

\section{Methods}

Drawing from the conceptual framework described above, this study addresses the following research questions:

1. To what extent do background characteristics, rank/tenure, teaching and scholarly activities, and perceptions of the institutional climate predict STEM faculty members' likelihood of involving undergraduate students in their research projects?

2. Controlling for individual characteristics, to what extent do institutional type, selectivity, and faculty's average perception of institutional priorities account for the variation across colleges and universities in STEM faculty members' average probability of involving undergraduate students in their research projects?

\section{Sample}

The sample for this study comes from the 2007-2008 Faculty Survey administered by UCLA's Higher Education Research Institute (HERI). Every 3 years, HERI administers a survey to a national sample of faculty across all disciplines and from all types of institutions. The survey collects information about the demographics of faculty, faculty members' responsibilities at their respective institutions, career trajectories, goals and priorities related to undergraduate education, and perceptions of institutional priorities (see DeAngelo et al. 2009 for more details about the survey and its methodology). In addition to administering the Faculty Survey through institutions that paid to participate in the survey, HERI also administered the survey to a supplemental sample of faculty and institutions using a stratified institutional sampling frame that ensured that all institutional types, with the exception of community colleges, were appropriately represented.

In addition to the institutional sampling frame employed by HERI, funding from the National Institutes of Health (NIH) and National Science Foundation (NSF) allowed for an additional sampling of STEM faculty with the Faculty Survey. This specific sample targeted faculty working at institutions that have strong reputations for conferring large numbers of STEM baccalaureate degrees as well as those working at minority-serving institutions. Within these institutions, we invited all STEM faculty to participate in the survey. When combined with the larger administration of the Faculty Survey through 
HERI, the sample of faculty available for this study included 6,036 STEM faculty members from 205 institutions.

Because this study seeks to identify the variables that predict faculty members' decisions to involve undergraduate students on their research project, we removed respondents who indicated that their primary responsibility at their institution was administration as well as respondents who said that they had no contact with undergraduate students. After deleting cases with missing data for the outcome and for key demographic characteristics (such as gender and race/ethnicity), we arrived at a final analytic sample of 4,832 STEM undergraduate teaching faculty within 194 colleges and universities. For the current study, the faculty data were merged with 2007-2008 academic year data from the Integrated Postsecondary Education Data System.

\section{Variables}

The dependent variable for this study is a dichotomous measure that asked: "During the past 2 years, have you engaged undergraduates on your research project?" Faculty could respond yes or no. Table 1 provides the coding scheme for the dependent variable as well as for all independent variables used in the analyses, and Table 2 provides descriptive statistics for each variable. Approximately $61 \%$ of faculty in the sample reported having engaged undergraduate students on their research projects in the last two years.

We grouped our independent variables into blocks according to prior literature and our conceptual framework. Given that prior research has suggested there may be differences in faculty workload by personal characteristics (Antonio 2002; Bellas and Toutkoushian 1999), the first block of variables included demographic characteristics, such as sex, race, and native language. Asian American, Latino, Black, and Native American represent four separate dichotomous variables with White as the reference group.

In the second and third blocks of variables, we accounted for characteristics of faculty members' professional career, including their tenure status, rank, and discipline, as well as the amount of time they have worked at their present institution. This latter variable was derived from taking the difference between the year of appointment and 2008, as the vast majority of faculty completed the Faculty Survey in the spring and summer of 2008. For faculty rank, associate professor served as the reference group with professor, assistant professor, lecturer, and instructor representing dichotomous variables. Among disciplines, we controlled for faculty affiliated with engineering and computer science departments, health science departments, or physical science departments, and we used life sciences as the reference group. Appendix A contains a list of the specific fields that each of these general disciplinary areas encompass.

Given the expanding workload of faculty (Jacobs and Winslow 2004; Link et al. 2008), it is important to account for activities that might constrain the amount of time faculty have to work with undergraduates on research. Prior research has suggested that faculty who spend more time teaching may have less time to devote to research and may also have less time to provide the mentorship and oversight necessary to work with undergraduates on research projects (Fairweather 2002; Schuster and Finkelstein 2006). Therefore, we accounted for a host of scholarly and teaching activities in blocks four, five and six. Block four focuses on teaching activities, such as teaching an honors course, an interdisciplinary course, a course exclusively on the Internet, or a first-year seminar. In this block, we also controlled for the number of graduate courses that faculty taught and the hours per week faculty were scheduled to teach during the term in which they completed the survey. Block five controls for scholarly activities other than teaching, like the amount of time faculty 
Table 1 Description of variables and measures

Variables Scale range

Dependent variable

Engaged undergraduates on your research project (last 2 years)

Demographic characteristics

Sex: female

Native language: English

Racial/Ethnic Background (White is reference group)

Asian
Latino
Black

Native American

Professional career

Tenured

Time since appointed at present institution (in years)

Rank (Associate Professor is reference group)

Full Professor

Assistant Professor

Lecturer

Instructor

Discipline (Life sciences is reference group)

Engineering and computer science

Health sciences

Physical sciences

Teaching activities

Taught an honors course (last 2 years)

Taught an interdisciplinary course (last 2 years)

Taught a course exclusively on the Internet (last 2 years)

Taught a seminar for first-year students (last 2 years)

Number of Graduate courses taught (this academic year)
$0=$ no, $1=$ yes

$1=$ male, 2 = female

$1=$ no, $2=$ yes

$0=$ no, $1=$ yes

$0=$ no, $1=$ yes

$0=$ no, $1=$ yes

$0=$ no, $1=$ yes

$0=$ no, $1=$ yes

Continuous, $\min =0, \max =54$

$0=$ no, $1=$ yes

$0=$ no, $1=$ yes

$0=$ no, $1=$ yes

$0=$ no, $1=$ yes

$0=$ no, $1=$ yes

$0=$ no, $1=$ yes

$0=$ no, $1=$ yes

$1=$ no, $2=$ yes

$1=$ no, $2=$ yes

$1=$ no, $2=$ yes

$1=$ no, $2=$ yes

Continuous, $\min =0.49, \max =6$

HPW teaching (actual, not credit hours) (average week during $1=$ none, $9=45+$ hours this term)

Other scholarly activities

Collaborated with the local community in research/teaching $1=$ no, $2=$ yes (last 2 years)

Advised student groups involved in service/volunteer work $1=$ no, $2=$ yes (last 2 years)

HPW research and scholarly writing (average week during $1=$ none, $9=45+$ hours this term)

Extent: engage in academic work that spans multiple disciplines

Extent: mentor new faculty

$1=$ not at all, $3=$ to a great extent

$1=$ not at all, $3=$ to a great extent

Publications and funding

Number of articles published in academic or professional $\quad 1=$ none, $7=51+$ journals (career)

Number of published books, manuals, or monographs (career) $1=$ none, $7=51+$ 
Table 1 continued

\begin{tabular}{|c|c|}
\hline Variables & Scale range \\
\hline $\begin{array}{l}\text { Number of writings published/accepted for publication } \\
\text { (last } 2 \text { years) }\end{array}$ & $1=$ none, $7=51+$ \\
\hline $\begin{array}{l}\text { Received funding for your work from: foundations } \\
\text { (last } 2 \text { years) }\end{array}$ & $1=$ no, $2=$ yes \\
\hline $\begin{array}{l}\text { Received funding for work from: State/federal government } \\
\text { (last } 2 \text { years) }\end{array}$ & $1=$ no, $2=$ yes \\
\hline $\begin{array}{l}\text { Received funding for your work from: business or industry } \\
\text { (last } 2 \text { years) }\end{array}$ & $1=$ no, $2=$ yes \\
\hline \multicolumn{2}{|c|}{ Goals for undergraduates (importance of goals for undergraduate students) } \\
\hline Promote ability to write effectively & $1=$ not important, $4=$ essential \\
\hline $\begin{array}{l}\text { Help students evaluate the quality and reliability } \\
\text { of information }\end{array}$ & $1=$ not important, $4=$ essential \\
\hline Encourage student habits of mind for learning (factor) & Continuous, $\min =-4.15, \max =1.37$ \\
\hline Goal for undergrads: enhance social understanding (factor) & Continuous, $\min =-1.89, \max =1.62$ \\
\hline \multicolumn{2}{|l|}{ Institutional climate } \\
\hline Institutional priority prestige (factor) & Continuous, $\min =-2.33, \max =1.33$ \\
\hline $\begin{array}{l}\text { Faculty are rewarded for their efforts to work with } \\
\text { underprepared students (at this institution) }\end{array}$ & $1=$ not descriptive, $3=$ very descriptive \\
\hline $\begin{array}{l}\text { Faculty feel that most students are well-prepared } \\
\text { academically (at this institution) }\end{array}$ & $1=$ not descriptive, $3=$ very descriptive \\
\hline $\begin{array}{l}\text { Faculty here are strongly interested in the academic } \\
\text { problems of undergraduates (at this institution) }\end{array}$ & $1=$ not descriptive, $3=$ very descriptive \\
\hline My research is valued by faculty in my department & $\begin{array}{l}1=\text { Disagree strongly, } 4=\text { Agree } \\
\text { strongly }\end{array}$ \\
\hline $\begin{array}{l}\text { My values are congruent with the dominant institutional } \\
\text { values }\end{array}$ & $\begin{array}{l}1=\text { Disagree strongly, } 4=\text { Agree } \\
\text { strongly }\end{array}$ \\
\hline There is adequate support for faculty development & $\begin{array}{l}1=\text { Disagree strongly, } 4=\text { Agree } \\
\text { strongly }\end{array}$ \\
\hline \multicolumn{2}{|l|}{ Institutional characteristics } \\
\hline Faculty average: importance of research & Continuous, $\min =1.50, \max =4.00$ \\
\hline Faculty average: institutional priority is prestige & Continuous, $\min =-2.20, \max =1.17$ \\
\hline HBCU & $1=$ no, $2=$ yes \\
\hline Institution has a medical center & $1=$ no, $2=$ yes \\
\hline Institutional control: private & $1=$ public, $2=$ private \\
\hline $\begin{array}{l}\text { Liberal arts institution (masters comprehensive is the } \\
\text { reference group) }\end{array}$ & $0=$ no, $1=$ yes \\
\hline $\begin{array}{l}\text { Doctoral institution (masters comprehensive is the reference } \\
\text { group) }\end{array}$ & $0=$ no, $1=$ yes \\
\hline Institutional selectivity ( 1 unit $=100$ pt. change) & Continuous, $\min =8.38, \max =14.67$ \\
\hline
\end{tabular}

spend on research each week, the extent to which faculty mentor new faculty at their institution and whether they advised student groups involved with volunteer work. Mentoring new faculty and advising student groups served as proxies for faculty members' commitment to mentorship in their work (McManus and Russell 1997; Organ and Ryan 1995); we hypothesized that such a commitment may translate into an increased 
Table 2 Descriptive statistics (faculty $N=4,832$, Institutional $N=194$ )

\begin{tabular}{|c|c|c|c|c|}
\hline & Mean & SD & Min & $\operatorname{Max}$ \\
\hline \multicolumn{5}{|l|}{ Dependent variable } \\
\hline Included undergraduate students on your research project & 0.61 & 0.48 & 0.00 & 1.00 \\
\hline \multicolumn{5}{|l|}{ Demographic characteristics } \\
\hline Sex: female & 1.33 & 0.47 & 1.00 & 2.00 \\
\hline Is English your native language? & 1.85 & 0.36 & 1.00 & 2.00 \\
\hline Asian & 0.07 & 0.26 & 0.00 & 1.00 \\
\hline Latino & 0.01 & 0.10 & 0.00 & 1.00 \\
\hline Black & 0.02 & 0.14 & 0.00 & 1.00 \\
\hline Native American & 0.01 & 0.11 & 0.00 & 1.00 \\
\hline \multicolumn{5}{|l|}{ Professional career } \\
\hline Tenured & 0.65 & 0.48 & 0.00 & 1.00 \\
\hline Time since appointed at present institution & 14.20 & 10.76 & 0.00 & 54.00 \\
\hline Full Professor & 0.40 & 0.49 & 0.00 & 1.00 \\
\hline Assistant Professor & 0.23 & 0.42 & 0.00 & 1.00 \\
\hline Lecturer & 0.04 & 0.19 & 0.00 & 1.00 \\
\hline Instructor & 0.04 & 0.20 & 0.00 & 1.00 \\
\hline \multicolumn{5}{|l|}{ Discipline (life sciences is the reference group) } \\
\hline Engineering and computer science & 0.24 & 0.43 & 0.00 & 1.00 \\
\hline Health sciences & 0.18 & 0.38 & 0.00 & 1.00 \\
\hline Physical sciences & 0.34 & 0.47 & 0.00 & 1.00 \\
\hline \multicolumn{5}{|l|}{ Teaching activities } \\
\hline Taught an honors course & 1.18 & 0.39 & 1.00 & 2.00 \\
\hline Taught an interdisciplinary course & 1.40 & 0.49 & 1.00 & 2.00 \\
\hline Taught a course exclusively on the Internet & 1.09 & 0.29 & 1.00 & 2.00 \\
\hline Taught a seminar for first-year students & 1.21 & 0.41 & 1.00 & 2.00 \\
\hline Number of graduate courses taught & 1.83 & 1.06 & 1.00 & 6.00 \\
\hline Hrs/week Scheduled teaching (actual, not credit hours) & 3.27 & 1.28 & 1.00 & 9.00 \\
\hline \multicolumn{5}{|l|}{ Other scholarly activities } \\
\hline Collaborated with the local community in research/teaching & 1.43 & 0.50 & 1.00 & 2.00 \\
\hline Advised student groups involved in service/volunteer work & 1.37 & 0.48 & 1.00 & 2.00 \\
\hline Hrs/week Research and scholarly writing & 3.89 & 2.12 & 1.00 & 9.00 \\
\hline Extent: engage in academic work that spans multiple disciplines & 2.20 & 0.68 & 1.00 & 3.00 \\
\hline Extent: mentor new faculty & & & & \\
\hline \multicolumn{5}{|l|}{ Publications and funding } \\
\hline Number of articles published in academic or professional journals (career) & 4.74 & 1.88 & 1.00 & 7.00 \\
\hline Number of published books, manuals, or monographs (career) & 1.51 & 0.85 & 1.00 & 7.00 \\
\hline $\begin{array}{l}\text { Number of professional writings published/accepted for publication in the } \\
\text { last two years }\end{array}$ & 2.84 & 1.35 & 1.00 & 7.00 \\
\hline Received funding for your work from: foundations & 1.28 & 0.45 & 1.00 & 2.00 \\
\hline Received funding for your work from: state or federal government & 1.55 & 0.50 & 1.00 & 2.05 \\
\hline Received funding for your work from: business or industry & 1.25 & 0.43 & 1.00 & 2.00 \\
\hline \multicolumn{5}{|l|}{ Goals for undergraduates } \\
\hline Promote ability to write effectively & 3.52 & 0.63 & 1.00 & 4.00 \\
\hline Help students evaluate the quality and reliability of information & 3.61 & 0.57 & 1.00 & 4.00 \\
\hline
\end{tabular}


Table 2 continued

\begin{tabular}{|c|c|c|c|c|}
\hline & Mean & SD & Min & Max \\
\hline Encourage student habits of mind for learning (factor) & -0.01 & 0.92 & -4.15 & 1.37 \\
\hline Goal for undergrads: enhance social understanding (factor) & -0.05 & 0.90 & -1.89 & 1.62 \\
\hline \multicolumn{5}{|l|}{ Institutional climate } \\
\hline Institutional priority prestige (factor) & 0.00 & 0.91 & -2.33 & 1.33 \\
\hline Faculty are rewarded for their efforts to work with underprepared students & 1.49 & 0.60 & 1.00 & 3.00 \\
\hline Faculty feel that most students are well-prepared academically & 2.40 & 0.82 & 1.00 & 4.00 \\
\hline $\begin{array}{l}\text { Faculty here are strongly interested in the academic problems of } \\
\text { undergraduates }\end{array}$ & 3.18 & 0.72 & 1.00 & 4.00 \\
\hline My research is valued by faculty in my department & 2.97 & 0.82 & 1.00 & 4.00 \\
\hline My values are congruent with the dominant institutional values & 2.88 & 0.76 & 1.00 & 4.00 \\
\hline There is adequate support for faculty development & 2.75 & 0.78 & 1.00 & 4.00 \\
\hline \multicolumn{5}{|l|}{ Institutional characteristics } \\
\hline Faculty average: importance of research & 3.13 & 0.47 & 1.50 & 4.00 \\
\hline Faculty average: importance of teaching & 3.69 & 0.21 & 3.00 & 4.00 \\
\hline Faculty average: institutional priority is prestige (factor) & -0.12 & 0.52 & -2.20 & 1.17 \\
\hline HBCU & 1.09 & 0.28 & 1.00 & 2.00 \\
\hline Institution has a medical center & 1.11 & 0.31 & 1.00 & 2.00 \\
\hline Institutional control: private & 1.53 & 0.50 & 1.00 & 2.00 \\
\hline Liberal arts institution & 0.35 & 0.48 & 0.00 & 1.00 \\
\hline Doctoral institution & 0.48 & 0.50 & 0.00 & 1.00 \\
\hline Institutional selectivity & 11.18 & 1.54 & 8.38 & 14.76 \\
\hline
\end{tabular}

likelihood of mentoring undergraduate students through engaging them in research opportunities.

Block six examines the predictive power of faculty members' productivity, as measured by the number of published pieces across different media, and the extent to which faculty have secured funding to support their research. Receiving financial support for research may have a positive association with faculty members' likelihood to involve undergraduates in their research projects, as such funding may enable faculty to pay undergraduates or may even require them to include undergraduates on their research team as part of a training component (Einarson and Clarkberg 2004). NIH and NSF often have supplemental grants for faculty to include training components in research grants; these components are designed to encourage faculty to include undergraduate students on their research teams.

The seventh block of independent variables contains indicators of faculty members' goals for undergraduate education. Specifically, we included faculty members' perceived importance of promoting students' writing ability, helping students evaluate the quality and reliability of information, encouraging habits of mind for learning, and enhancing students' social understanding. Encouraging students' habits of mind for learning and enhancing students' social understanding represented latent constructs, and Table 3 includes additional information on these factors. We used principal axis factoring with promax rotation to identify all factors used in the analyses, and we calculated the factor scores by weighting each component variable by its factor loading, calculating the weighted sum, and standardizing the resulting distribution. 
Table 3 Multi-item factors

\begin{tabular}{|c|c|}
\hline Scale and items & Factor loadings \\
\hline Encourage student habits of mind for learning & $\alpha=0.84$ \\
\hline \multicolumn{2}{|l|}{ In your interactions with undergraduates, how often do you encourage them to* } \\
\hline Seek alternative solutions to a problem & .65 \\
\hline Evaluate the quality or reliability of information they receive & .64 \\
\hline Explore topics on their own, even though it was not required for a class & .61 \\
\hline Seek feedback on their academic work & .60 \\
\hline Seek solutions to problems and explain them to others & .59 \\
\hline Take risks for potential gains & .58 \\
\hline Support their opinions with a logical argument & .57 \\
\hline Look up scientific research articles and resources & .56 \\
\hline Acknowledge failure as a necessary part of the learning process & .55 \\
\hline Revise their papers to improve their writing & .53 \\
\hline Ask questions in class & .47 \\
\hline \multicolumn{2}{|l|}{$* 1=$ Not at all, $2=$ Occasionally, $3=$ Frequently } \\
\hline Institutional priority prestige & $\alpha=0.79$ \\
\hline \multicolumn{2}{|l|}{ Indicate how important you believe each priority listed below is at your college/university** } \\
\hline To enhance the institution's national image & .84 \\
\hline To increase or maintain institutional prestige & .78 \\
\hline To hire faculty stars & .69 \\
\hline To pursue extramural funding & .49 \\
\hline \multicolumn{2}{|l|}{$* * 1=$ Low priority, $2=$ Medium priority, $3=$ High priority, $4=$ Highest priority } \\
\hline Goal for undergraduates: enhance social understanding & $\alpha=0.79$ \\
\hline \multicolumn{2}{|c|}{ Indicate the importance to you of each of the following education goals for undergrad students*** } \\
\hline Enhance students' knowledge of and appreciation for other racial/ethnic groups & .83 \\
\hline Encourage students to become agents of social change & .76 \\
\hline Enhance students' self-understanding & .64 \\
\hline$* * * 1=$ Not important, $2=$ Somewhat important, $3=$ Very important, $4=\mathrm{E}$ & \\
\hline
\end{tabular}

The final block of faculty-level variables included measures of faculty members' perceptions of the climate at their institution. Specifically, in this block of variables we examined the association between our outcome and a factor measuring faculty's perceptions of the extent to which their institution places a high priority on advancing institutional prestige (see Table 3) as well as variables representing respondents' opinions regarding whether the institution rewards them for their efforts in working with underprepared students, the extent to which they feel that students are well-prepared academically, and the extent to which faculty feel their colleagues in their department value their research. These measures were in part designed to capture the organizational climate that might relate to faculty's interaction with students, as the organizational climate may affect faculty members' commitment to the organization and their propensity to engage in behavior that goes beyond prescribed job responsibilities (McManus and Russell 1997; Organ and Ryan 1995).

Finally, the last block in our analysis accounted for institution-level measures of the context in which faculty work, as workload and mentorship activities vary significantly 
across institutions (Townsend and Rosser 2007). We included dichotomous measures corresponding to whether the institution is a historically Black college or university (HBCU), a private institution, a liberal arts college or doctoral/research university (comprehensive master's is the reference group), and whether the institution houses a medical center. Additionally, we included a measure of institutional selectivity, which we calculated based on the average SAT scores of entering students; we re-scaled this variable so that a one-unit increase represents a 100-point increase in average institutional selectivity. Finally, we incorporated two aggregated measures from the faculty survey: the extent to which faculty at each institution believe their institution places a high priority on advancing institutional prestige and the extent to which faculty believe research is important.

\section{Missing Data}

Before proceeding with our multivariate analysis, we analyzed the extent to which data were missing in our sample. We deleted 18 cases that had missing data on the outcome variable, demographic characteristics, or other dichotomous variables. After removing these cases, we utilized the expectation-maximization (EM) algorithm to impute values for missing data. Through the use of maximum likelihood estimates, the EM algorithm replaces missing values for specified variables in the dataset; this algorithm provides a more accurate estimation of values for missing data than other less robust methods, such as mean replacement (McLachlan and Krishnan 1997). McLachlan and Krishnan (1997) recommend that analysts use the EM method only when a small proportion of data is missing for a given variable. In our sample, no variable had more than $7 \%$ of cases with missing data, a proportion which we judged small, so we replaced data for all relevant variables.

\section{Analyses}

The primary analytic technique used in this study was hierarchical generalized linear modeling (HGLM). HGLM is the most appropriate statistical technique to use when analyzing multi-level data to predict a dichotomous outcome (Raudenbush and Bryk 2002). Our data have a clustered design, as faculty are nested within institutions; HGLM accounts for the inherent hierarchical nature of such data and provides robust standard errors to reduce the likelihood of Type I statistical errors (Raudenbush and Bryk 2002). Furthermore, because this method appropriately partitions variance in the outcome between individuals (faculty) and groups (institutions), we are able to more accurately estimate the unique effects of institutional contexts on faculty members' likelihood to involve undergraduate students in research projects.

In building models within HGLM, analysts must ensure that the outcome significantly varies across institutions. To do this, we analyzed the random variance component from a fully unconditional model, which is a model without any predictors, to determine whether faculty's average probability of involving undergraduates in research significantly differed across colleges and universities. The fully unconditional model suggested that institutions significantly differed in the average proportion of faculty involving undergraduates in research, so we proceeded with building the level-one model, which is shown in Eq. 1: 


$$
\begin{aligned}
\log \left[\frac{\Phi i j}{1-\Phi i j}\right]= & \beta_{0 \mathrm{j}+} \beta_{1 \mathrm{j}}(\text { DEMOGRAPHIC CHARACTERISTICS })_{\mathrm{ij}} \\
& +\beta_{2 \mathrm{j}}(\text { PROFESSIONAL CAREER })_{\mathrm{ij}} \\
& +\beta_{3 \mathrm{j}}(\text { DISCIPLINE })_{\mathrm{ij}}+\beta_{4 \mathrm{j}}(\text { TEACHING ACTIVITIES })_{\mathrm{ij}} \\
& +\beta_{5 \mathrm{j}}(\text { OTHER SCHOLARLY ACTIVITIES })_{\mathrm{ij}} \\
& +\beta_{6 \mathrm{j}}(\text { PUBLICATIONS AND FUNDING })_{\mathrm{ij}} \\
& +\beta_{7 \mathrm{j}}(\text { GOALS FOR UNDERGRADUATES })_{\mathrm{ij}} \\
& +\beta_{8 \mathrm{j}}(\text { INSTITUTIONAL CLIMATE })_{\mathrm{ij}}
\end{aligned}
$$

where the term on the left side of the equation refers to the likelihood that faculty member $i$ in institution $j$ involved undergraduates in his or her research project. The terms $B_{1 j}-B_{8 j}$ represent the individual coefficients corresponding to each variable in the model. For the sake of simplicity we do not present every variable in our model in Eq. 1; instead, the vectors of variables listed above refer to the blocks of variables previously described and presented in Table 1 . We allowed the intercept $\left(\beta_{0 \mathrm{j}}\right)$ to vary across institutions because the fully unconditional model suggested that the average probability of faculty involving undergraduates in their research differed significantly across institutions.

To examine the factors that account for this variation across colleges and universities, we constructed a model for institution-level variables, which is given by Eq. 2:

$$
\mathrm{B}_{0 \mathrm{j}}=\gamma_{00}+\gamma_{01}(\text { INSTITUTIONAL CHARACTERISTICS })_{\mathrm{j}}+\mu_{\mathrm{j}}
$$

where $j$ denotes the institution, and $\gamma_{01}$ refers to the coefficients associated with the variables within that block, which are measured on an institutional level. Finally, $\mu_{\mathrm{j}}$ represents the randomly varying error term in the level-2 model, and $\gamma_{00}$ represents the grand mean probability (i.e. the mean for the whole sample) of involving undergraduates in research.

Two additional notes about our method are warranted. First, when utilizing multilevel modeling techniques, it is important to consider how variables are centered, as centering affects the interpretation of the intercept. We chose to grand-mean center all continuous variables and leave all dichotomous variables uncentered (Raudenbush and Bryk 2002), as the focus of our study did not involve interpreting the intercept of Eq. 1. Finally, to improve interpretation of the findings, we report all of our significant results as delta$p$ statistics. Delta- $p$ statistics correspond to the expected change in probability of involving an undergraduate in a faculty research project for every one-unit change in the independent variable. We relied on the recommended method by Petersen (1985) to calculate the delta$p$ statistics.

\section{Limitations}

Before discussing the results from the HGLM analyses, it is important to note several limitations of this study. First, as with any study that analyzes secondary data, we are limited by the variables that were included on the 2007-2008 HERI Faculty Survey. For example, our outcome variable measures only whether faculty members involved undergraduate students on their research projects in the last two years, and we are therefore unable to say that faculty members who did not involve students on research projects in the past two years have never done so. Further, using just this variable we also are unable to 
determine the extent of the undergraduates' involvement on the project, nor the level of engagement faculty had with these students. Further, because this study analyzed crosssectional data, we cannot infer causality. Faculty participants responded to all survey items at the same point in time, and therefore we cannot conclude whether certain perceptions or actions led to faculty members' decision to include undergraduate students on research projects or whether such engagement prompted the perceptions and experiences that faculty reported on the survey. Finally, our sample of STEM faculty is not a random sample; instead, our sample includes STEM faculty from a representative stratified set of institutions within the U.S., as the supplemental sample identified with the NSF and NIH funding increased the diversity of institutions represented.

\section{Results}

We present the results from the HGLM analyses in Table 4. For simplicity, we present only the findings from the final model, which included both faculty- and institution-level predictors. Our results suggest that the institutional context has a significant association with faculty members' probability of engaging undergraduates in their research projects. For example, faculty who worked at an $\mathrm{HBCU}$ were 17.03 percentage points more likely involve undergraduates on their research projects than were their colleagues at predominantly White institutions and Hispanic-serving institutions. Additionally, faculty who taught at liberal arts colleges were more than 13 percentage points more likely than their peers at masters comprehensive institutions to include undergraduate students in research. Institutional selectivity also significantly and positively predicted faculty's inclusion of undergraduates on research projects, as a 100-point increase in institutions' selectivity corresponded to a 3.50 percentage-point increase in faculty members' average probability of involving undergraduates in research. The institutional variables in the model accounted for $59 \%$ of the between-institution variance in the average probability of engaging undergraduates on faculty research projects.

Considering individual predictors of faculty members' decision to include undergraduate students in research projects, we found that demographic characteristics did not have a significant association with the outcome. By contrast, several of the professional, careerrelated characteristics were significant predictors. For example, faculty who had worked at an institution for a longer period of time tended to have a lower probability of engaging undergraduate students in research. Every additional year working at an institution was associated with a small but significant 0.48 percentage-point reduction in the probability of working with undergraduates on research.

Faculty in disciplines other than life sciences had significantly lower likelihoods of involving undergraduates in research than did those in life sciences. Specifically, faculty in engineering and computer science departments were approximately 17 percentage points less likely than their colleagues in life science departments to include undergraduates in research. The negative association doubled when comparing health sciences faculty to their peers in the life sciences, as health sciences faculty were almost 35 percentage points less likely than their colleagues in the life sciences to involve undergraduates in their research. Finally, faculty in physical science disciplines were almost 20 percentage points less likely than respondents in the life sciences to include undergraduates in research.

Turning to teaching and other scholarly activities, our results show a significant and positive association between involving undergraduates in a faculty member's research project and teaching an honors course (delta- $p=9.63 \%$ ) or an interdisciplinary course 
Table 4 Hierarchical Generalized Linear Modeling (HGLM) results for faculty's propensity to include undergraduates on their research project(s)

\begin{tabular}{|c|c|c|c|c|}
\hline Faculty $N=4,832$, Institutional $N=194$ & Log odds & $\mathrm{SE}$ & $\Delta-\mathrm{P}$ & Sig. \\
\hline \multicolumn{5}{|l|}{ Demographic characteristics } \\
\hline Sex: female & -0.09 & 0.11 & & 0.62 \\
\hline Native language: English & 0.11 & 0.17 & & 0.34 \\
\hline Asian & 0.02 & 0.27 & & 0.84 \\
\hline Latino & 0.79 & 0.78 & & 0.28 \\
\hline Black & 0.13 & 0.37 & & 0.78 \\
\hline Native American & -0.09 & 0.49 & & 0.88 \\
\hline \multicolumn{5}{|l|}{ Professional career } \\
\hline Tenured & 0.08 & 0.22 & & 0.72 \\
\hline Time since appointed at present institution & -0.02 & 0.01 & $-0.48 \%$ & 0.00 \\
\hline Professor & -0.10 & 0.15 & & 0.48 \\
\hline Assistant Professor & 0.30 & 0.25 & & 0.23 \\
\hline Lecturer & -0.54 & 0.40 & & 0.18 \\
\hline Instructor & -0.61 & 0.39 & & 0.12 \\
\hline \multicolumn{5}{|l|}{ Discipline (life sciences is the reference group) } \\
\hline Engineering and computer science & -0.69 & 0.14 & $-17.04 \%$ & 0.00 \\
\hline Health sciences & -1.47 & 0.16 & $-34.55 \%$ & 0.00 \\
\hline Physical sciences & -0.81 & 0.11 & $-19.97 \%$ & 0.00 \\
\hline \multicolumn{5}{|l|}{ Teaching activities } \\
\hline Taught an honors course & 0.43 & 0.16 & $9.63 \%$ & 0.01 \\
\hline Taught an interdisciplinary course & 0.25 & 0.11 & $5.76 \%$ & 0.02 \\
\hline Taught a course exclusively on the Internet & -0.24 & 0.19 & & 0.21 \\
\hline Taught a seminar for first-year students & 0.17 & 0.15 & & 0.14 \\
\hline Number of undergraduate courses taught this term & 0.07 & 0.05 & & 0.17 \\
\hline Number of graduate courses taught & -0.15 & 0.06 & $-3.69 \%$ & 0.01 \\
\hline Hrs/week scheduled teaching (actual, not credit hours) & 0.08 & 0.05 & & 0.13 \\
\hline \multicolumn{5}{|l|}{ Other scholarly activities } \\
\hline $\begin{array}{l}\text { Collaborated with the local community in research/ } \\
\text { teaching }\end{array}$ & 0.35 & 0.12 & $7.94 \%$ & 0.00 \\
\hline $\begin{array}{l}\text { Advised student groups involved in service/volunteer } \\
\text { work }\end{array}$ & 0.31 & 0.12 & $7.08 \%$ & 0.01 \\
\hline Hrs/Week Research and scholarly writing & 0.21 & 0.04 & $4.87 \%$ & 0.00 \\
\hline $\begin{array}{l}\text { Extent: engage in academic work that spans multiple } \\
\text { disciplines }\end{array}$ & 0.24 & 0.09 & $5.51 \%$ & 0.01 \\
\hline Extent: mentor new faculty & 0.22 & 0.09 & $5.09 \%$ & 0.03 \\
\hline \multicolumn{5}{|l|}{ Publications and funding } \\
\hline $\begin{array}{l}\text { Number of articles published in academic/professional } \\
\text { journals (career) }\end{array}$ & 0.19 & 0.05 & $4.41 \%$ & 0.00 \\
\hline $\begin{array}{l}\text { Number of published books, manuals, or monographs } \\
\text { (career) }\end{array}$ & -0.16 & 0.08 & $-3.87 \%$ & 0.04 \\
\hline $\begin{array}{l}\text { Number of professional writings published/accepted for } \\
\text { publication in the last } 2 \text { years }\end{array}$ & 0.11 & 0.08 & & 0.14 \\
\hline Source of stress: research or publishing demands & 0.38 & 0.09 & $8.58 \%$ & 0.00 \\
\hline Received funding for your work from: foundations & 0.38 & 0.13 & $8.58 \%$ & 0.01 \\
\hline
\end{tabular}


Table 4 continued

\begin{tabular}{|c|c|c|c|c|}
\hline Faculty $N=4,832$, Institutional $N=194$ & Log odds & SE & $\Delta-\mathrm{P}$ & Sig \\
\hline $\begin{array}{l}\text { Received funding for your work from: state or federal } \\
\text { government }\end{array}$ & 0.61 & 0.13 & $13.22 \%$ & 0.00 \\
\hline $\begin{array}{l}\text { Received funding for your work from: business or } \\
\text { industry }\end{array}$ & 0.34 & 0.14 & $7.73 \%$ & 0.02 \\
\hline \multicolumn{5}{|l|}{ Goals for undergraduates } \\
\hline Promote ability to write effectively & 0.10 & 0.10 & & 0.31 \\
\hline $\begin{array}{l}\text { Help students evaluate the quality and reliability } \\
\text { of information }\end{array}$ & 0.18 & 0.11 & & 0.10 \\
\hline Encourage student habits of mind for learning (factor) & 0.29 & 0.06 & $6.64 \%$ & 0.00 \\
\hline $\begin{array}{l}\text { Goal for undergrads: enhance social understanding } \\
\text { (factor) }\end{array}$ & -0.13 & 0.07 & & 0.06 \\
\hline \multicolumn{5}{|l|}{ Institutional climate } \\
\hline Institutional priority prestige (factor) & -0.04 & 0.07 & & 0.61 \\
\hline $\begin{array}{l}\text { Faculty are rewarded for their efforts to work with } \\
\text { underprepared students }\end{array}$ & -0.14 & 0.09 & & 0.13 \\
\hline $\begin{array}{l}\text { Faculty feel that most students are well-prepared } \\
\text { academically }\end{array}$ & 0.15 & 0.07 & $3.50 \%$ & 0.03 \\
\hline $\begin{array}{l}\text { Faculty here are strongly interested in the academic } \\
\text { problems of undergraduates }\end{array}$ & 0.16 & 0.07 & $3.65 \%$ & 0.02 \\
\hline My research is valued by faculty in my department & 0.13 & 0.06 & $3.04 \%$ & 0.05 \\
\hline $\begin{array}{l}\text { My values are congruent with the dominant institutional } \\
\text { values }\end{array}$ & -0.13 & 0.07 & & 0.06 \\
\hline \multicolumn{5}{|l|}{ Institutional characteristics } \\
\hline Faculty average: importance of research & 0.17 & 0.20 & & 0.38 \\
\hline Faculty average: institutional priority is prestige & -0.21 & 0.22 & & 0.33 \\
\hline $\mathrm{HBCU}$ & 0.82 & 0.41 & $17.03 \%$ & 0.05 \\
\hline Institution has a medical center & -0.45 & 0.30 & & 0.13 \\
\hline Institutional control: private & -0.22 & 0.16 & & 0.15 \\
\hline Liberal arts institution & 0.60 & 0.20 & $13.03 \%$ & 0.00 \\
\hline Doctoral institution & -0.19 & 0.20 & & 0.36 \\
\hline Institutional selectivity & 0.15 & 0.05 & $3.50 \%$ & 0.01 \\
\hline Intercept & -2.30 & 0.87 & & \\
\hline Variance at level-2 & 0.06 & & & \\
\hline Explained variance at level-2 & 0.59 & & & \\
\hline
\end{tabular}

(delta- $p=5.76 \%$ ). By contrast, faculty who taught more graduate courses tended to have a lower likelihood of involving undergraduate students in a research project within the last two years (delta- $p=-3.69 \%$ ). Holding all else constant, it seemed as if faculty who were more active in research were more likely to offer opportunities for research to undergraduates. Respondents who reported that they collaborated with the local community in their teaching or research were approximately 8 percentage points more likely to have undergraduates involved on their research projects, and those who spent more time each week engaged in research were also more likely to include undergraduates in their research-almost 5 percentage points more likely for each unit increase in research hours per week. Finally, respondents who indicated that they advised student groups involved in 
volunteer work had a 7.08 percentage-point greater likelihood of engaging undergraduates in research than their peers who did not advise such student groups.

In terms of faculty respondents' level of productivity and funding sources, we found that faculty who had published more journal articles throughout their careers tended to be significantly more likely to include undergraduates in their research projects (delta$p=4.41 \%$ ). However, we also found that faculty who published more books, manuals, or monographs over the course of their careers had a lower probability of engaging undergraduate students in research (delta- $p=-3.87 \%$ ). The number of publications within the last two years did not have a significant association with the outcome variable. In terms of funding, the results in Table 4 suggest that faculty who had received funding for their research had significantly higher probabilities of engaging undergraduate students in research. Respondents who had received funding from foundations were 8.58 percentage points more likely to engage undergraduates in their research projects compared to their peers who did not receive such monies. Likewise, receiving funding from business or industry corresponded to a 7.73 percentage-point increase in the probability of including undergraduates in research. State or federal government grants had the strongest association with faculty's decision to include undergraduate students on research projects, as faculty who had received a grant from a state or federal agency were 13.22 percentage points more likely to have undergraduate students working on their research projects compared to their colleagues who did not have state or federal research dollars.

Results connected to faculty members' goals for undergraduate education were mixed. Feeling strongly about promoting students' ability to write effectively, helping students evaluate the quality and reliability of information, and developing students' social understanding had no significant association with faculty members' propensity to involve undergraduate students in research. By contrast, the factor measuring faculty members' commitment to encouraging students' development of scholarly habits of mind for learning had a significant and positive association with the outcome. For every one-standard deviation increase in the habits of mind factor, faculty members' probability of including undergraduate students on a research project increased by 6.64 percentage points.

In the last block of individual-level predictors, three of the six perceptions of institutional climate significantly predicted the outcome variable. Faculty who believed that students at their institution are well-prepared academically tended to have a higher probability of including undergraduate students on their research projects (delta$p=3.50 \%$ ), as did respondents who reported that, in general, faculty at their institution are strongly interested in the academic problems of students (delta- $p=3.65 \%$ ). Lastly, faculty who felt that their departmental colleagues value their research tended to be significantly more likely to include undergraduates in their research (delta- $p=3.04 \%$ ).

\section{Discussion}

In this study we utilized the frameworks of social exchange theory and organizational citizenship behavior to understand why faculty members decide to involve undergraduate students on their research projects. To that end, we considered how institutional contexts and individual behaviors and perceptions affect faculty members' probabilities of deciding to include undergraduates on research projects. From an institutional perspective, we found a large and significant gap in the probability of working with undergraduate students on faculty-directed research projects between HBCUs and primarily White institutions (PWIs) and Hispanic-serving institutions (HSIs). Faculty who worked at HBCUs were significantly 
more likely to engage undergraduates in research than were their peers at other kinds of institutions. This finding connects to other research that has suggested that HBCUs offer their students a more supportive and collaborative environment than do PWIs and HSIs (Nelson Laird et al. 2007). The finding also connects to work by Allen (1992) and Hurtado et al. (2009), which found higher levels of support and engagement among both students and faculty within HBCUs. Hurtado (2003) has suggested that HBCUs have unique, student-centered missions, and these missions may be driving faculty members' decision to include undergraduates on their research projects because supportive environments may extend to faculty members' willingness to mentor undergraduate students.

With regard to institutional type, our findings suggest that faculty who work at liberal arts colleges tended to have significantly higher probabilities of including undergraduates on research projects than do their peers at masters comprehensive universities. Faculty who work at liberal arts colleges are typically less known for their research productivity than they are for their commitment to undergraduate education, as these institutions often emphasize teaching over research and require faculty to teach substantially more hours each week than do masters comprehensive or doctoral/research universities (Milem et al. 2000; Schuster and Finkelstein 2006). It may be the case that the smaller class sizes and more intimate campus environments allow faculty at liberal arts colleges to connect with undergraduates in ways that their peers at larger, more research-intensive institutions cannot, and these connections increase faculty members' willingness to involve undergraduates on their research projects. From a social exchange theory perspective, it may also be the case that faculty at liberal arts institutions have few, if any, graduate students with whom they can collaborate on research, so they may see faculty-student research projects as more mutually beneficial than do faculty at institutions enrolling more graduate students. Supporting this hypothesis, we found that faculty members at doctoral/research institutions were not significantly more or less likely than those at master's comprehensive institutions to involve students in research, which may be explained by the fact that both types of institutions generally enroll enough graduate students to populate faculty labs. It may also be that these institutions are not significantly different after taking into account faculty who are the most actively engaged in sponsored project research with external funds.

We found that faculty at more selective institutions had significantly higher probabilities of including undergraduates on their research projects, and this finding may connect to the overall preparation of students. Similar to our individual-level finding that showed a positive association between faculty members' perception of students' academic preparedness and their likelihood of involving students in research, the positive association between selectivity and involving undergraduate students in research may be the result of a sense that well-prepared students need less oversight and orientation to research projects. If better-prepared students can adapt quickly to a research project, students may indeed promote, rather than hinder, faculty members' research productivity (Harvey and Thompson 2009). Additionally, faculty at more selective institutions typically have a larger pool of high-achieving students from which to draw for their research projects.

Perhaps most strongly connected to the framework of organizational citizenship behavior are our findings that relate to the individual-level associations between institutional climate measures and faculty members' likelihoods of working with undergraduates on research. Faculty who indicated that their departmental colleagues valued their research tended to have an increased likelihood of including undergraduates in research. Likewise, faculty who felt that others at their institution are strongly interested in undergraduates' academic problems significantly and positively predicted faculty members' inclusion of 
undergraduate students in research projects. These findings relate to having a positive attitude regarding the work (or campus) environment, which organizational citizenship behavior theory suggests increases employees' likelihoods of assuming responsibilities outside of their prescribed duties (McManus and Russell 1997; Organ and Ryan 1995). Faculty who retain a generally positive or optimistic attitude about the undergraduate students on their campus and who feel valued by their colleagues are more likely to take the extra step of working with undergraduates even if reward system and productivity disincentives exist. From this perspective, our climate-related findings also support results from previous studies that connect faculty morale and job satisfaction to faculty members' commitment to their work (Johnsrud and Rosser 2002; Rosser 2004).

Similarly, one of the faculty goals related to undergraduate education had a significant and positive association with faculty members' likelihood of including undergraduate students on research projects. Faculty who felt more strongly about improving students' habits of mind for learning had a significantly higher probability of involving undergraduates in research. Believing that it is their duty to improve the way that undergraduates think and work may demonstrate faculty members' commitment to undergraduate education, and a natural result of this commitment could be the understanding of the benefits that students get from working on research projects (Espinosa 2009; Hunter et al. 2006; Laursen et al. 2010; Seymour et al. 2004). Providing opportunities to develop students' scientific competencies could be thought of, under a social exchange theory framework, as a reward that faculty receive from the relationship. Additionally, through the lens of organizational citizenship behavior, faculty members' commitment to undergraduate education may prompt them to want to improve undergraduate students' experience regardless of the presence of any tangible incentive to do so (McManus and Russell 1997; Organ and Ryan 1995).

Our results suggest that spending more "face time" with undergraduate students generally corresponds to an increased probability of including them on research projects. Faculty who taught honors or interdisciplinary courses or who advised student groups were significantly more likely to engage undergraduates in research. Having more contact with undergraduates, particularly in intimate settings like honors classes or student groups, may improve faculty members' perceptions of working with undergraduates on research, especially as they relate to any perceived disincentives of reduced productivity (Harvey and Thompson 2009; Prince et al. 2007). Furthermore, having positive working relationships with undergraduates could improve faculty members' job satisfaction and general morale (Johnsrud and Rosser 2002; Rosser 2004), which are both thought to enhance an individual's likelihood of performing duties outside his or her prescribed responsibilities.

Not surprisingly, securing funding for research had a significant, positive association with involving undergraduates in faculty-directed research projects. Although some undergraduates may pursue research opportunities solely for the hands-on training and mentorship they expect to receive, many also use such opportunities as a way to earn supplemental funding toward financing their undergraduate degree. Faculty who secure research dollars have a greater potential to not only be able to offer undergraduates the experience of doing research but also to provide the financial support students seek. Not all funding sources seemed to function in the same way, however, as we found that faculty who secured funding from state or federal agencies were nearly twice as likely as their peers who received funding from foundations or industry to engage undergraduates in research. This notable difference between sources of funding may relate to the fact that some government-sponsored grants have an undergraduate training requirement through which faculty receive additional funds mandated to be spent on research opportunities for 
undergraduate students. NSF and NIH typically provide funding to faculty for including training components in research grants as a way to incentivize faculty to include undergraduates and underrepresented students on their project. From a policy standpoint, these training components serve as an effective method for NSF and NIH to expand undergraduate research opportunities in addition to the direct funding these and other organizations provide for structured undergraduate research programs.

\section{Conclusions and Implications}

Our findings suggest that institutional administrators who view undergraduate research as an important component of STEM education would be well-served to try to increase faculty members' commitment to the institution and to undergraduate education, or to hire faculty who explicitly possess these commitments. Faculty who believe in strengthening undergraduate education by helping undergraduate students achieve key goals were more likely to report having worked with undergraduates on research projects within the previous two years. Similarly, faculty who had more positive perceptions of the preparation of undergraduate students also tended to have significantly higher probabilities of involving undergraduates in their research.

Although our dataset lacked variables related to faculty members' perceptions of their institution's reward and incentive structures, several findings from our analyses suggest that reshaping the incentive structure may increase faculty members' probability of involving undergraduates in research. For example, faculty who volunteered to advise student groups were significantly more likely to include undergraduates in research. Likewise, respondents who taught interdisciplinary courses or worked with the community in their research and teaching activities also tended to be more likely to include undergraduates in research. These activities may merely relate to an individual faculty member's proclivity to exceed core responsibilities at their institution, but, by incentivizing such activities or others that are connected to mentorship, institutions have an opportunity to increase faculty members' engagement with undergraduate students. If institutions provide incentives for faculty engagement with undergraduate students, they may increase faculty members' likelihoods of involving undergraduates in research.

Further, our analyses suggest that faculty members who feel that their research is valued by members of their department are more likely than those who do not feel this way to involve undergraduates on their research projects. Such an association may in part stem from an understanding or an expectation of these faculty members that providing opportunities for undergraduates to work on their research projects will be rewarded-or has been rewarded - in their department's review and tenure process. O'Meara and Braskamp (2005) note that "eliciting greater faculty engagement with students means affecting expectations for faculty work and the structures and conditions of their careers" (p. 226). By expanding reward structures that "include a broadened definition of scholarship," administrators can begin rewarding faculty who engage regularly with students, serve as mentors, connect their research to the local community, and participate in less traditional forms of scholarship and publishing (O’Meara and Braskamp 2005, p. 232). Given the amount of time faculty may spend facilitating the intellectual and social development of their protégés, institutions that value undergraduate education have an obligation to recognize such an investment of time and energy on the part of faculty.

By implementing incentives that encourage faculty members to mentor undergraduate students through research experiences, college administrators can institutionalize the kinds 
of structured undergraduate research programs that are currently funded by organizations like NSF and NIH. These programs are often funded for only a limited timeframe and already rely on faculty members' willingness to work with undergraduate students on research projects. If institutions incentivize the inclusion of undergraduates on research either through the tenure and promotion system or through institutional grants that offer undergraduate research training components, college administrators can sustain undergraduate research experiences long after the external funding for structured programs has expired.

The current research project only examined whether or not faculty members include undergraduates in research. Future research needs to begin to consider the types of opportunities for research that faculty members offer to undergraduate students in science. The quality and type of research experiences likely varies considerably across faculty and the students with whom they work. A fuller accounting of what research experiences involve, both in terms of faculty time and effort as well as student learning and engagement, would offer a more complex understanding as to how to reward faculty who offer these experiences and how to encourage students to take advantage of such opportunities.

By increasing faculty members' willingness to engage undergraduates in research, colleges and universities can take a proactive step in improving undergraduate outcomes, particularly in STEM education. The benefits that students derive from participation in such experiences range from increased commitment to scientific disciplines to improved academic performance to increased likelihood of STEM degree completion (Cole and Espinosa 2008; Espinosa 2009; Hunter er al. 2006; Laursen et al. 2010; Seymour et al. 2004). Although undergraduate research experiences represent just one component of a more comprehensive effort to improve undergraduate STEM outcomes, these opportunities may provide an efficient, cost-effective means of increasing students' likelihood to successfully advance along STEM educational pathways.

Hurtado et al. (2008) emphasized the importance of the structure of opportunity in providing research experiences to undergraduate science students. Faculty have a role in facilitating these opportunities, particularly in institutions where formal structured programs do not exist. However, without tangible incentives to create research opportunities, many faculty may decide to involve undergraduate students in research projects solely as a result of good organizational citizenship behavior. In other words, only those faculty who feel strongly about mentoring or who understand the mutual benefits of collaborating with students will offer research opportunities to undergraduates. Creating institutional incentives for faculty to work with undergraduates on research will not only reward those faculty who already encourage students to work with them but will also provide motivation for other faculty to begin to engage with undergraduates in a similar fashion. Relying on a few faculty members to volunteer to exceed their prescribed core responsibilities is not a sustainable way to provide research opportunities to undergraduates or to advance scientific talent for the nation. For institutions to develop and sustain undergraduate research programs, they need the support of their faculty. To get the support of faculty, institutions need to provide appropriate support and rewards to the teachers, researchers, and mentors who are largely responsible for educating, expanding, and diversifying the scientific workforce.

Acknowledgements This study was made possible by the support of the National Institute of General Medical Sciences, NIH Grant Numbers 1 R01 GMO71968-01 and R01 GMO71968-05 as well as the National Science Foundation, NSF Grant Number 0757076. This independent research and the views expressed here do not indicate endorsement by the sponsors. 
Open Access This article is distributed under the terms of the Creative Commons Attribution Noncommercial License which permits any noncommercial use, distribution, and reproduction in any medium, provided the original author(s) and source are credited.

\section{Appendix A: Categorization of Disciplinary Affiliations}

Life Sciences

Agriculture

Forestry

Bacteriology, Molecular Biology

Biochemistry

Biophysics

Botany

Environmental Science

Marine (life) Sciences

Physiology, Anatomy

Zoology

General, Other Biological Sciences

Engineering and Computer Science

Aero-/Astronautical Engineering

Chemical Engineering

Civil Engineering

Electrical Engineering

Industrial Engineering

Mechanical Engineering

General, Other Engineering Fields

Computer Science

Data Processing, Computer Programming

Health Sciences

Dentistry

Health Technology

Medicine or Surgery

Nursing

Pharmacy, Pharmacology

Therapy (speech, physical, occup.)

Veterinary Medicine

General, Other Health Fields

Physical Sciences

Mathematics and/or Statistics

Astronomy

Atmospheric Sciences

Chemistry

Earth Sciences 


\author{
Geography \\ Marine Sciences (incl. Oceanography) \\ Physics \\ General, Other Physical Sciences
}

\title{
References
}

Aguirre, A., Jr. (2000). Women and minority faculty in the academic workplace: Recruitment, retention, and academic culture. (ASHE/ERIC Higher Education Research Report, No. 27). Washington, DC: Association for the Study of Higher Education.

Allen, W. R. (1992). The color of success: African-American college student outcomes at predominantly White and historically Black public colleges and universities. Harvard Educational Review, 62(1), 26-44.

Antonio, A. L. (2002). Faculty of color reconsidered: Reassessing contributions to scholarship. The Journal of Higher Education, 73(5), 582-602.

Bellas, M., \& Toutkoushian, R. (1999). Faculty time allocations and research productivity: Gender, race and family effects. The Review of Higher Education, 22(4), 367-390.

Blackburn, R. T., \& Lawrence, J. H. (1995). Faculty at work: Motivation, expectation, satisfaction. Baltimore, MD: Johns Hopkins University Press.

Bland, C. J., Center, B. A., Finstad, D. A., Risbey, K. R., \& Staples, J. G. (2005). A theoretical, practical, predictive model of faculty and department research productivity. Academic Medicine, 80(2), 225-237.

Campbell, T. A., \& Campbell, D. E. (1997). Faculty/student mentor program: Effects on academic performance and retention. Research in Higher Education, 38(6), 727-742.

Cole, D., \& Espinoza, A. (2008). Examining the academic success of Latino students in science technology engineering and mathematics (STEM) majors. Journal of College Student Development, 49(4), 285-300.

Committee on Science, Engineering, and Public Policy. (2007). Rising above the gathering storm: Energizing and employing America for a brighter economic future. Retrieved February 25, 2008, from National Academies Press website, http://www.nap.edu/catalog/11463.html

Crisp, G., \& Cruz, I. (2009). Mentoring college students: A critical review of the literature between 1990 and 2007. Research in Higher Education, 50(6), 525-545.

Davis, D., Poste, J., \& Kelly, D. (2005). The UCSD research associate program: A recipe for successfully integrating undergraduates with emergency medicine research. The Journal of Emergency Medicine, 28(1), 89-93.

DeAngelo, L., Hurtado, S. H., Pryor, J. H., Kelly, K. R., Santos, J. L., \& Korn, W. S. (2009). The American college teacher: National norms for the 2007-2008 HERI Faculty Survey. Los Angeles: Higher Education Research Institute, UCLA.

Doherty, J. (1988). Psychological morale: Its conceptualisation and measurement. The Doherty Inventory of Psychological Morale (DIPM). Educational Studies, 14(1), 65-74.

Einarson, M., \& Clarkberg, M. (2004). Understanding faculty out-of-class interaction with undergraduate students at a research university. Ithaca, NY: Cornell Higher Education Research Institute (CHERI), Cornell University.

Emerson, R. M. (1981). Social exchange theory. In M. Rosenberg \& R. H. Turner (Eds.), Social psychology: Sociological perspectives (pp. 30-65). New York: Basic Books, Inc.

Espinosa, L. (2009). Pipelines and pathways: Women of color in STEM majors and the experiences that shape their persistence. Unpublished doctoral dissertation.

Fairweather, J. S. (1993). Faculty reward structures: Toward institutional and professional homogenization. Research in Higher Education, 34(5), 603-623.

Fairweather, J. S. (1997). The NEA 1997 almanac of higher education. Washington, DC: National Education Association.

Fairweather, J. S. (2002). The mythologies of faculty productivity: Implications for institutional policy and decision making. The Journal of Higher Education, 73(1), 26-48.

Fairweather, J. S. (2005). Beyond the rhetoric: Trends in the relative value of teaching and research in faculty salaries. The Journal of Higher Education, 76(4), 401-422.

Fairweather, J. S., \& Beach, A. (2002). Variations in faculty work at research universities: implications for state and institutional policy. The Review of Higher Education, 26(1), 97-115.

Gibb, S. (1999). The usefulness of theory: A case study in evaluating formal mentoring schemes. Human Relations, 52(8), 1055-1075. 
Griffin, K. A. (2008). Can reaching back push you forward? A mixed methods exploration of Black faculty and the developmental relationships with students. Unpublished doctoral dissertation.

Harvey, L., \& Thompson, K. (2009, May/June). Approaches to undergraduate research and their practical impact on faculty productivity in the natural sciences. Journal of College Science Teaching, May/June 2009, 12-13.

Hegstad, C. D. (1999). Formal mentoring as a strategy for human resource development: A review of research. Human Research Development Quarterly, 10(A), 383-390.

Herzberg, F. (1966). Work and the nature of man. Cleveland: World Publishing Company.

Higher Education Research Institute. (2010). Degrees of success: Bachelor's degree completion rates among initial STEM majors. Retrieved on March 1, 2010, from http://www.heri.ucla.edu/nih/ HERI_ResearchBrief_OL_2010_STEM.pdf

Huang, G., Taddese, N., \& Walter, E. (2000). Entry and persistence of women and minorities in college science and engineering education (No. NCES 2000601). Washington, D.C.: National Center for Education Statistics.

Hunter, A. B., Laursen, S. L., \& Seymour, E. (2006). Becoming a scientist: The role of undergraduate research in students' cognitive, personal, and professional development. Science Education, 91(1), 36-74.

Hurtado, S. (2003). Institutional diversity in American higher education. In S. R. Komives, J. Woodard, D. B. \& Associates (Eds.), Student services: A handbook for the profession (4th ed., pp. 23-44). San Francisco: Jossey-Bass.

Hurtado, S., Cabrera, N. L., Lin, M. H., Arellano, L., \& Espinosa, L. L. (2009). Diversifying science: Underrepresented student experiences in structured research programs. Research in Higher Education, 50(2), 189-214.

Hurtado, S., Eagan, M. K., Cabrera, N., Lin, M., Park, J., \& Lopez, M. (2008). Training future scientists: Factors predicting underrepresented minority student participation in undergraduate research. Research in Higher Education, 49(2), 126-152.

Ishiyama, E. (2007). Expectations and perceptions of undergraduate research mentoring: Comparing first generation, low-income white/Caucasian and African American students. College Student Journal, 41(3), 540-549.

Jacobi, M. (1991). Mentoring and undergraduate academic success: A literature review. Review of Educational Research, 61(4), 505-532.

Jacobs, J., \& Winslow, S. (2004). The academic life course, time pressures and gender inequality. Community, Work \& Family, 7(2), 143-161.

Johnson, W. B. (2002). The intentional mentor: Strategies and guidelines for the practice of mentoring. Professional Psychology, Research and Practice, 33(1), 88-96.

Johnson, W. B. (2007). On being a mentor: A guide for higher education faculty. Mahwah, NJ: Lawrence Erlbaum Associates, Inc.

Johnsrud, L. K., \& Rosser, V. R. (2002). Faculty members' morale and their intention to leave: A multilevel explanation. The Journal of Higher Education, 73(4), 518-542.

Judge, T. A., Bono, J. E., Thoresen, C. J., \& Patton, G. K. (2001). The job satisfaction-Job performance relationships: A qualitative and quantitative review. Psychological Bulletin, 127(3), 376-407.

Kardash, C. M. (2000). Evaluation of an undergraduate research experience: Perceptions of undergraduate interns and their faculty mentors. Journal of Educational Psychology, 92(1), 191-201.

Laursen, S., Seymour, E., Hunter, A. B., Thiry, H., \& Melton, G. (2010). Undergraduate research in the sciences: Engaging students in real science. San Francisco: Jossey-Bass.

Lawler, E. J., \& Thye, S. R. (1999). Bringing emotions into social exchange theory. Annual Review of Sociology, 25(1), 217-244.

Lee, W. Y. (1999). Striving toward effective retention: The effect of race on mentoring African American students. Peabody Journal of Education, 74(2), 27-43.

Link, A., Swann, C., \& Bozeman, B. (2008). A time allocation study of university faculty. Economics of Education Review, 27(4), 363-374.

Mamiseishvili, K., \& Rosser, V. J. (2010). International and citizen faculty in the United States: An examination of their productivity at research universities. Research in Higher Education, 51(1), 88-107.

McLachlan, G. J., \& Krishnan, T. (1997). The EM algorithm and extensions. New York: Wiley.

McManus, S. E., \& Russell, J. E. A. (1997). New directions for mentoring research: An examination of related constructs. Journal of Vocational Behavior, 51(1), 145-161.

Merkel, C. A. (2001). Undergraduate research at six research universities: A pilot study for the Association of American Universities. California Institute of Technology. Retrieved October 20, 2009, from http://www.aau.edu/education/Merkel.pdf 
Milem, J. F., Berger, J. B., \& Dey, E. L. (2000). Faculty time allocation: A study of change over twenty years. The Journal of Higher Education, 71(4), 454-475.

Nelson Laird, T. F., Bridges, B. K., Morelon-Quainoo, C. L., Williams, J. M., \& Holmes, M. S. (2007). African American and Hispanic student engagement at minority serving and predominantly White institutions. Journal of College Student Development, 48(1), 39-56.

Newby, T. J., \& Heide, A. (2008). The value of mentoring. Performance Improvement Quarterly, 5(4), $2-15$.

O’Meara, K. A., \& Braskamp, L. (2005). Aligning faculty reward systems and development to promote faculty and student growth. NASPA Journal, 42(2), 223-240.

Olsen, D., Maple, S. A., \& Stage, F. K. (1995). Women and minority faculty job satisfaction: Professional role interests, professional satisfactions, and institutional fit. The Journal of Higher Education, 66(3), 267-293.

Organ, D. W. (1988). Organizational citizenship behavior: The good soldier syndrome. Lexington, MA: Lexington Books.

Organ, D. W., \& Ryan, K. (1995). A meta-analytic review of attitudinal and dispositional predictors of organizational citizenship behavior. Personnel Psychology, 48(4), 775-802.

Park, S. M. (1996). Research, teaching, and service: Why shouldn't women's work count? Journal of Higher Education, 67(1), 46-84.

Petersen, T. (1985). A comment on presenting results from logit and probit models. American Sociological Review, 50(1), 130-131.

Porter, S. R., \& Umbach, P. D. (2001). Analyzing faculty workload data using multilevel modeling. Research in Higher Education, 42(2), 171-196.

Prince, M., Felder, R., \& Brent, R. (2007). Does faculty research improve undergraduate teaching? An analysis of existing and potential synergies. Journal of Engineering Education, 96(4), 283-294.

Raudenbush, S. W., \& Bryk, A. S. (2002). Hierarchical linear models: Applications and data analysis methods. Thousand Oaks, CA: Sage Publications, Inc.

Rice, R. (1986). The academic profession in transition: Toward a new social fiction. Teaching Sociology, $14(1), 12-23$.

Rosser, V. J. (2004). Faculty members' intentions to leave: A national study on their worklife and satisfaction. Research in Higher Education, 45(3), 285-309.

Santos, S. J., \& Reigadas, E. T. (2002). Latinos in higher education: An evaluation of a university facutly mentoring program. Journal of Hispanic Higher Education, 1(1), 40-50.

Schuster, J. H., \& Finkelstein, M. J. (2006). The American faculty: The restructuring of academic work and careers. Baltimore: Johns Hopkins.

Seymour, E., Hunter, A.-B., Laursen, S., \& Deantoni, T. (2004). Establishing the benefits of research experiences for undergraduates in the sciences: First findings from a three-year study. Science Education, 88(4), 493-534.

Sharobeam, M., \& Howard, K. (2002). Teaching demands versus research productivity. Journal of College Science Teaching, 31(7), 436-441.

Townsend, B., \& Rosser, V. (2007). Workload issues and measures of faculty productivity. Thought \& Action, 23, 7-19.

Turner, C. S. V. (2002). Women of color in academe: Living with multiple marginality. The Journal of Higher Education, 73(1), 74-93.

Van Dyne, L., Graham, J. W., \& Dienesch, R. M. (1994). Organizational citizenship behavior: Construct redefinition, measurement, and validation. The Academy of Management Journal, 37(4), 765-802. 